\title{
Effects of diazepam/ketamine and xylazine/ketamine sedation in geese
}

\author{
Andrija Musulin'1, Matija Škulac², Mirta Vučković́1, Andrea Martinović1, \\ Petar Kostešić1, Nika Brkljača Bottegaro ${ }^{1}$, Marko Pećin ${ }^{1}$, \\ and Dražen Vnuk ${ }^{1}$
}

${ }^{I}$ Clinic for Surgery, Orthopaedics and Ophthalmology, Faculty of Veterinary Medicine, University of Zagreb, Zagreb, Croatia

${ }^{2}$ Private practice "Vetosan", Osijek, Croatia

\section{MUSULIN, A., M. ŠKULAC, M. VUČKOVIĆ, A. MARTINOVIĆ, P. KOSTEŠIĆ, N. BRKLJAČA BOTTEGARO, M. PEĆIN, D. VNUK: Effects of diazepam/ketamine and xylazine/ketamine sedation in geese. Vet. arhiv 88, 835-846, 2018.}

\section{ABSTRACT}

The objective of this paper was to compare the effects of diazepam/ketamine and xylazine/ketamine combinations administered intramuscularly to geese, by measurement of the duration of individual anaesthesia periods, and, by exploring their effect on the respiratory and cardiovascular systems, to ascertain which combination is safer or better to use in geese. Eight geese received the combination of xylazine and ketamine, eight received the combination of diazepam and ketamine, and six received a $0.9 \% \mathrm{NaCl}$ solution. Body temperature, breathing and pulse rate were monitored, while biochemical testing and determination of the acidbasic state of venous blood was performed before the administration of the agent, 5 minutes after administration, and after geese began to raise their heads. The geese from the control group were subjected to the additional measurements 35 minutes after saline administration. The period from anaesthetic administration to setting the head on the ground was significantly shorter in geese receiving diazepam/ketamine than in the geese receiving xylazine/ketamine. The time period from setting the head on the ground to the time of the first reaction to pressure on the distal phalanx, and the time from administration to the time of standing up was significantly longer in geese receiving diazepam/ketamine than in geese receiving xylazine/ketamine. The venous $\mathrm{CO}_{2}$ partial pressure was significantly higher during anaesthesia in the xylazine/ketamine group. According to the results of this study, it may be concluded that the anaesthesia of geese with the diazepam/ketamine combination showed more favourable effects than the anaesthesia with the xylazine/ketamine combination.

Key words: anaesthesia; geese; cardiorespiratory effects

\footnotetext{
*Corresponding author:

Andrija Musulin, DVM, PhD., Clinic for Surgery, Orthopaedics and Ophtalmology, Faculty of Veterinary Medicine, University of Zagreb, Heinzelova 55, 10000 Zagreb, Croatia, Phone: +385 12390 390; Fax: +385 12441 390; E-mail: andrijamusulin@ gmail.com

ISSN 0372-5480
}

Printed in Croatia 


\section{Introduction}

Birds, particularly wild birds, present specific problems regarding their physiological, anatomic and metabolic differences from mammals. Their high metabolic rate requires more frequent food intake, and therefore, abstaining from feeding for 6 to 8 hours can result in strong or even fatal hypoglycaemia and ketosis. The respiratory system in birds differs from that of mammals, with one obvious difference in that inhalation in birds is typically passive, while exhalation is active. Gas exchange occurs during both inhalation and exhalation, and its efficacy depends on the uninterrupted flow of air through the lungs. Even short periods of apnoea are serious and can cause significant hypoxia (HALL et al., 2001).

The proper choice of anaesthetic is essential in the performance of all small or large surgical procedures in birds. Although inhalation anaesthesia is recommended for birds, the unavailability of mobile anaesthesia equipment, especially for wild birds, and its use in field conditions makes this option generally unfeasible (CURRO, 1998). Injection anaesthetics offer certain benefits over inhalation anaesthetics, including the minimum amount of equipment required, fast application, and low cost (MACHIN and CAULKETT, 1998).

The objective of this study was to compare the effects of the combinations diazepam/ ketamine and xylazine/ketamine in the anaesthesia of geese. The duration of anaesthesia periods in geese and the impacts of each combination on the respiratory and cardiovascular system were examined in order to determine which combination is more acceptable for use in geese.

\section{Materials and methods}

The study was performed on 22 domestic geese (Anser anser domesticus) of the Drava breed. All geese were females, aged 7 months, with an average body weight of 4.97 $\pm 0.26 \mathrm{~kg}$ (mean \pm standard deviation). The geese were kept together in a flock, in housing with standard microclimatic conditions. Fresh water was available at all times, and feed was administered ad libitum. This experiment was approved by the Ethical Committee of the Veterinary Faculty in Zagreb and the Ministry of Agriculture.

All geese were healthy, as confirmed by a general clinical examination. Feed was removed 4 hours prior to the anaesthesia, and water 2 hours prior. Body temperature, breathing frequency and pulse was measured in geese from all three groups prior to anaesthesia.

Venous blood was drawn from a cannula installed in the venus ulnaris for haematological and biochemical testing (AST, glucose, sodium, potassium, calcium and chloride), and for determination of the acid-base status. Venous blood for determination of acid-base status was taking in a heparinised capillary tube (Clinitubes, $1.63 \times 115$ 
$\mathrm{mm}$, Radiometer Medical, Denmark). The heparinised capillary tubes were then placed on ice and delivered to the laboratory within one hour. The acid-base status of venous blood was determined on a GEM Premier 3000 (Instrumentation Laboratory, Milano, Italy). Haematological and biochemical analysis were performed within two hours of taking blood samples. Haematological analysis was performed using an Şysmex K-4500 analyser (Sysmex Corporation, Kobe, Japan) and biochemical analysis using an Olympus AU 400 analyser (Olympus Corporation, Shinjuku-ku, Tokyo, Japan)

Prior to the start of the anaesthesia, the geese were randomly divided into three groups. Group 1, consisting of eight animals, received intramuscular (to the thigh) administration of xylazine (Rompun, Bayer, Leverkusen, Germany) in a dose of $3 \mathrm{mg} / \mathrm{kg}$, and ketamine (Ketaminol, Intervet, Boxmeer, Netherlands) in a dose of $40 \mathrm{mg} / \mathrm{kg}$.

Group 2 also consisted of eight animals, and received intramuscular administration of diazepam (Apaurin, Krka, Novo Mesto, Slovenia) in a dose of $4 \mathrm{mg} / \mathrm{kg}$, and ketamine in a dose of $40 \mathrm{mg} / \mathrm{kg}$.

Group 3 consisted of six animals that received $4.5 \mathrm{~mL}$ of a $0.9 \% \mathrm{NaCl}$ solution intramuscularly (Natrii chloridi infundibile, $0.9 \%$, Pliva, Zagreb, Croatia).

The animals were transferred to a room isolated from noise, light and draft, and with stable microclimate conditions. They were monitored for any changes in behaviour during anaesthesia, and the time when the animal sat down, i.e. when the animal set its head on the ground, was recorded. The animals were then monitored to determine the first reaction to pressure on the distal phalanx with a Pean haemostat, until they were able to lift their heads independently, and the time each animal was on its feet again. The following times were recorded:

t1 - time from the administration of anaesthetic to the time the goose sat on the ground

t2 - time from the administration of anaesthetic to when it set its head on the ground

t3 - time from lowering the head to the ground to the first reaction to pressure on the distal phalanx with a Pean haemostat

t4 - time from setting the head on the ground to the time of raising the head

t5 - time from setting the head on the ground to the time of standing up

t6 - time from the administration of anaesthetic to the time of raising the head

$\mathrm{t} 7$ - time from the administration of anaesthetic to the time of standing up.

The body temperature, breathing frequency and pulse of each goose were monitored, and blood was drawn for haematological and biochemical tests, and to determine the venous acid-base status prior to the intramuscular administration of anaesthetic drugs or saline solution, again at 5 minutes after administration, and again after the geese began to raise their heads, or for the third group, at 35 minutes after the saline administration (the expected time for animals in the first two groups to begin raising their heads). 


\section{A. Musulin et al.: Diazepam/ketamine and xylazine/ketamine effects in geese}

During anaesthesia, the animals' reactions to pressure on the distal phalanx with a Pean haemostat was measured every 5 minutes (flapping their wings, retracting their legs, raising their head and neck), and the time of reaction was recorded.

The obtained values of the indicators were analysed using the software package Statistica 8.0 (StatSoft, Inc., 2008). Significance in the difference of individual indicators between the observed groups (different anaesthetic treatments) was determined using a GLM model for repeated samples, and tested with the LSD post hoc test, and set at $\mathrm{P}<0.01$.

\section{Results}

The duration of general anaesthesia in Groups 1 and 2 of geese treated with different combinations of anaesthetics is summarized in Table 1.

Table 1. Duration of general anaesthesia in Groups 1 and 2 of geese treated with different combinations of anaesthetics

\begin{tabular}{|c|c|c|}
\hline & Group 1 & Group 2 \\
\hline Time & Mean \pm SD & Mean \pm SD \\
\hline $\mathrm{t}_{1}(\mathrm{~min})$ & $2.08 \pm 1.63$ & $1.41 \pm 0.51$ \\
\hline $\mathrm{t}_{2}(\mathrm{~min})$ & $8.05 \pm 6.36$ & $3.33 \pm 1.37$ \\
\hline $\mathrm{t}_{3}(\mathrm{~min})$ & $12.38 \pm 3.30^{\mathrm{A}}$ & $20.45 \pm 2.83^{\mathrm{B}}$ \\
\hline $\mathrm{t}_{4}(\overline{\min })$ & $55.38 \pm 15.55$ & $66.57 \pm 16.54$ \\
\hline $\mathrm{t}_{5}(\mathrm{~min})$ & $118.46 \pm 45.43^{\mathrm{A}}$ & $202.58 \pm 60.46^{\mathrm{B}}$ \\
\hline $\mathrm{t}_{6}(\mathrm{~min})$ & $64.55 \pm 16.12$ & $78.59 \pm 10.15$ \\
\hline $\mathrm{t}_{7}(\min )$ & $135.50 \pm 39.37$ & $207.05 \pm 59.00$ \\
\hline
\end{tabular}

Values expressed as the mean \pm standard deviation. Values marked with large letters are statistically significant $(\mathrm{P}<0.01)$.

Condition values for all three groups of animals after the start of measurement (0), 5 minutes after administration (5), and after the start of raising the head (RH), or 35 minutes after the administration of saline solution (35) for the geese in Group 3 is summarized in Table 2.

No statistically significant differences were observed between the three groups for the values of the haematological parameters at the individual measurement times.

Values of aspartate aminotransferase (AST), blood glucose (Glu), sodium $\left(\mathrm{Na}^{+}\right)$, potassium $\left(\mathrm{K}^{+}\right)$, chloride $\left(\mathrm{Cl}^{-}\right)$and calcium $\left(\mathrm{Ca}_{2}^{+}\right)$ions in serum for all three groups after the initial measurement (0), 5 minutes after administration (5), and after the start of raising the head (RH), or 35 minutes after the administration of saline solution (35) for the geese in Group 3 are shown in Table 3. 
A. Musulin et al.: Diazepam/ketamine and xylazine/ketamine effects in geese

Table 2. Condition values for all three groups of animals at the initial measurement (0), 5 minutes after administration (5), and after the start of raising the head ( $\mathrm{RH})$, or 35 minutes after the administration of saline solution (35) for geese in Group 3.

\begin{tabular}{|l|c|c|c|c|}
\hline \multirow{2}{*}{ Indicator } & $\begin{array}{c}\text { Measurement } \\
\text { time }\end{array}$ & Group 1 & Group 2 & Group 3 \\
\hline \multirow{2}{*}{$\begin{array}{l}\text { Body } \\
\text { temperature }\left({ }^{\circ} \mathrm{C}\right)\end{array}$} & 0 & $40.37 \pm 0.42$ & $40.40 \pm 0.40$ & $40.70 \pm 0.10$ \\
\cline { 2 - 5 } & 5 & $38.74 \pm 1.30$ & $39.48 \pm 0.83$ & $40.10 \pm 0.46$ \\
\cline { 2 - 5 } & $\mathrm{RH}(35)$ & $37.26 \pm 1.10^{\mathrm{A}}$ & $38.92 \pm 0.80^{\mathrm{B}}$ & $40.00 \pm 0.36^{\mathrm{B}}$ \\
\cline { 2 - 5 } & 0 & $117.00 \pm 16.67$ & $116.00 \pm 8.90$ & $116.00 \pm 8.90$ \\
\cline { 2 - 5 } Pulse rate $(/ \mathrm{min})$ & 5 & $98.25 \pm 24.97$ & $94.87 \pm 14.73$ & $100.00 \pm 21.07$ \\
\cline { 2 - 5 } & $\mathrm{RH}(35)$ & $81.75 \pm 16.35$ & $94.62 \pm 12.38$ & $100.66 \pm 22.03$ \\
\cline { 2 - 5 } $\begin{array}{l}\text { Respiratory } \\
\text { rate(/min) }\end{array}$ & 0 & $17.75 \pm 2.81$ & $21.25 \pm 3.61$ & $16.00 \pm 2.00$ \\
\cline { 2 - 5 } & $\mathrm{RH}(35)$ & $8.62 \pm 4.62^{\mathrm{A}}$ & $13.37 \pm 3.78^{\mathrm{B}}$ & $16.67 \pm 3.05$ \\
\hline
\end{tabular}

Values expressed as the mean \pm standard deviation. Values marked with large letters are statistically significant $(\mathrm{P}<0.01)$.

Table 3. Values of aspartate aminotransferase (AST), blood glucose (Glu), sodium $\left(\mathrm{Na}^{+}\right)$, potassium $\left(\mathrm{K}^{+}\right)$, chloride $\left(\mathrm{Cl}^{-}\right)$and calcium $\left(\mathrm{Ca}_{2}^{+}\right)$ions in serum for all three groups after the initial measurement (0), 5 minutes after administration (5), and after the start of raising the head (RH), or 35 minutes after the administration of saline solution (35) for geese in Group 3.

\begin{tabular}{|c|c|c|c|c|}
\hline Indicator & Time & Group 1 & Group 2 & Group 3 \\
\hline \multirow{3}{*}{$\begin{array}{l}\text { AST } \\
(\mathrm{U} / \mathrm{L})\end{array}$} & 0 & $36.00 \pm 9.58$ & $45.75 \pm 51.55$ & $22.33 \pm 5.13$ \\
\hline & 5 & $45.25 \pm 15.02^{\mathrm{A}}$ & $147.50 \pm 152.05^{\mathrm{B}}$ & $22.67 \pm 2.08^{\mathrm{A}}$ \\
\hline & PG (35) & $68.63 \pm 39.42$ & $90.25 \pm 74.72$ & $17.33 \pm 3.79$ \\
\hline \multirow{3}{*}{$\begin{array}{l}\text { Glu } \\
(\mathrm{mmol} / \mathrm{L})\end{array}$} & 0 & $8.23 \pm 1.26$ & $8.33 \pm 1.37$ & $10.17 \pm 0.84$ \\
\hline & 5 & $7.61 \pm 1.24$ & $7.50 \pm 1.49$ & $8.93 \pm 3.48$ \\
\hline & PG (35) & $7.16 \pm 1.63$ & $7.43 \pm 3.24$ & $9.20 \pm 3.39$ \\
\hline \multirow{3}{*}{$\begin{array}{l}\mathrm{Na}^{+} \\
(\mathrm{mmol} / \mathrm{L})\end{array}$} & 0 & $144.50 \pm 3.42$ & $146.25 \pm 2.82$ & $150.33 \pm 2.08$ \\
\hline & 5 & $144.75 \pm 3.06$ & $148.25 \pm 1.91$ & $149.67 \pm 3.21$ \\
\hline & PG (35) & $146.50 \pm 4.00$ & $147.88 \pm 4.19$ & $150.67 \pm 3.06$ \\
\hline \multirow{3}{*}{$\begin{array}{l}\mathrm{K}^{+} \\
(\mathrm{mmol} / \mathrm{L})\end{array}$} & 0 & $6.48 \pm 3.07$ & $6.49 \pm 3.19$ & $4.37 \pm 1.81$ \\
\hline & 5 & $7.53 \pm 2.47$ & $5.56 \pm 1.82$ & $4.20 \pm 0.79$ \\
\hline & PG (35) & $6.38 \pm 2.73$ & $6.69 \pm 2.77$ & $3.77 \pm 0.72$ \\
\hline \multirow{3}{*}{$\begin{array}{l}\mathrm{Cl}^{-} \\
(\mathrm{mmol} / \mathrm{L})\end{array}$} & 0 & $107.13 \pm 3.23$ & $110.13 \pm 2.80$ & $112.00 \pm 6.08$ \\
\hline & 5 & $108.63 \pm 2.88$ & $112.25 \pm 3.06$ & $114.00 \pm 3.61$ \\
\hline & PG (35) & $106.88 \pm 2.03^{\mathrm{A}}$ & $113.13 \pm 2.85^{\mathrm{B}}$ & $121.33 \pm 16.92^{\mathrm{B}}$ \\
\hline
\end{tabular}


A. Musulin et al.: Diazepam/ketamine and xylazine/ketamine effects in geese

Table 3. Values of aspartate aminotransferase (AST), blood glucose (Glu), sodium $\left(\mathrm{Na}^{+}\right)$, potassium $\left(\mathrm{K}^{+}\right)$, chloride $\left(\mathrm{Cl}^{-}\right)$and calcium $\left(\mathrm{Ca}_{2}^{+}\right)$ions in serum for all three groups after the initial measurement (0), 5 minutes after administration (5), and after the start of raising the head (RH), or 35 minutes after the administration of saline solution (35) for geese in Group 3. (continued)

\begin{tabular}{|l|c|c|c|c|}
\hline Indicator & Time & Group 1 & Group 2 & Group 3 \\
\hline \multirow{2}{*}{$\begin{array}{l}\mathrm{Ca}^{2+} \\
(\mathrm{mmol} / \mathrm{L})\end{array}$} & 0 & $2.50 \pm 0.14$ & $2.69 \pm 0.26$ & $2.61 \pm 0.14$ \\
\cline { 2 - 5 } & 5 & $2.39 \pm 0.34$ & $2.65 \pm 0.13$ & $2.53 \pm 0.21$ \\
\cline { 2 - 5 } & PG (35) & $2.30 \pm 0.29$ & $2.53 \pm 0.26$ & $2.14 \pm 0.59$ \\
\hline
\end{tabular}

Values expressed as the mean \pm standard deviation. Values marked with large letters are statistically significant $(\mathrm{P}<0.01)$.

Table 4. Acid-base status of venous blood. Acidity values $(\mathrm{pH})$, carbon dioxide partial pressure $\left(\mathrm{pCO}_{2}\right)$, oxygen partial pressure $\left(\mathrm{pO}_{2}\right)$, bicarbonate concentration $\left(\mathrm{HCO}_{3}^{-}\right)$and total carbon dioxide $\left(\mathrm{tCO}_{2}\right)$ in venous blood for all three groups of geese at the initial measurement (0), 5 minutes after administration (5), and after the start of raising the head (RH), or 35 minutes after the administration of saline solution (35) for geese in group 3.

\begin{tabular}{|c|c|c|c|c|}
\hline Indicator & Time & Group 1 & Group 2 & Group 3 \\
\hline \multirow{3}{*}{$\mathrm{pH}$} & 0 & $7.31 \pm 0.11$ & $7.46 \pm 0.04$ & $7.39 \pm 0.13$ \\
\hline & 5 & $7.25 \pm 0.08^{\mathrm{A}}$ & $7.44 \pm 0.07^{\mathrm{B}}$ & $7.51 \pm 0.04^{\mathrm{B}}$ \\
\hline & PG(35) & $7.27 \pm 0.09^{\mathrm{A}}$ & $7.43 \pm 0.03^{\mathrm{B}}$ & $7.49 \pm 0.04^{\mathrm{B}}$ \\
\hline \multirow{3}{*}{$\begin{array}{l}\mathrm{pCO}_{2} \\
(\mathrm{kPa})\end{array}$} & 0 & $7.26 \pm 1.69^{\mathrm{A}}$ & $4.41 \pm 0.86^{\mathrm{B}}$ & $6.29 \pm 2.88^{\mathrm{AB}}$ \\
\hline & 5 & $8.58 \pm 1.43^{\mathrm{A}}$ & $5.19 \pm 1.55^{\mathrm{B}}$ & $4.56 \pm 0.20^{\mathrm{B}}$ \\
\hline & PG(35) & $9.08 \pm 2.04^{\mathrm{A}}$ & $4.88 \pm 0.27^{\mathrm{B}}$ & $5.02 \pm 0.26^{\mathrm{B}}$ \\
\hline \multirow{3}{*}{$\begin{array}{l}\mathrm{pO}_{2} \\
(\mathrm{kPa})\end{array}$} & 0 & $2.46 \pm 2.21^{\mathrm{A}}$ & $7.45 \pm 2.19^{\mathrm{B}}$ & $5.67 \pm 1.54^{\mathrm{AB}}$ \\
\hline & 5 & $2.54 \pm 2.90^{\mathrm{A}}$ & $7.87 \pm 3.58^{\mathrm{B}}$ & $5.80 \pm 1.86^{\mathrm{AB}}$ \\
\hline & $\mathrm{PG}(35)$ & $2.85 \pm 1.64^{\mathrm{A}}$ & $6.28 \pm 1.94^{\mathrm{B}}$ & $7.35 \pm 5.14^{\mathrm{B}}$ \\
\hline \multirow{3}{*}{$\begin{array}{l}\mathrm{HCO}_{3}^{-} \\
(\mathrm{mmol} / \mathrm{L})\end{array}$} & 0 & $26.71 \pm 4.07$ & $22.86 \pm 3.29$ & $26.40 \pm 4.30$ \\
\hline & 5 & $26.94 \pm 2.60$ & $25.20 \pm 3.65$ & $27.40 \pm 2.10$ \\
\hline & PG(35) & $29.50 \pm 1.88^{\mathrm{A}}$ & $24.23 \pm 2.60^{\mathrm{B}}$ & $28.53 \pm 1.17^{\mathrm{AB}}$ \\
\hline \multirow{3}{*}{$\begin{array}{l}\mathrm{tCO}_{2} \\
(\mathrm{mmol} / \mathrm{L})\end{array}$} & 0 & $28.41 \pm 4.18$ & $23.89 \pm 3.50$ & $27.83 \pm 5.00$ \\
\hline & 5 & $28.90 \pm 2.64$ & $26.39 \pm 3.92$ & $28.43 \pm 2.05$ \\
\hline & PG(35) & $31.61 \pm 2.22^{\mathrm{A}}$ & $25.34 \pm 2.66^{\mathrm{B}}$ & $29.67 \pm 1.12^{\mathrm{AB}}$ \\
\hline
\end{tabular}

Values expressed as the mean \pm standard deviation. Values marked with large letters are statistically significant $(\mathrm{P}<0.01)$.

Acid-base status of venous blood. The acidity values $(\mathrm{pH})$, carbon dioxide partial pressure $\left(\mathrm{pCO}_{2}\right)$, oxygen partial pressure $\left(\mathrm{pO}_{2}\right)$, bicarbonate concentration $\left(\mathrm{HCO}_{3}^{-}\right)$and total carbon dioxide $(\mathrm{tCO} 2)$ in venous blood for all three groups of geese after initial measurement (0), 5 minutes after administration (5), and after the start of raising the head 
(RH), or 35 minutes after the administration of saline solution (35) for geese in Group 3 are shown in Table 4. Convulsions appeared in 6 of 8 geese in the group receiving the combination of xylazine/ketamine and lasted on average 36.8 minutes. The same convulsions, though lasting only one-third the time, 12.34 minutes, were observed in 3 of 8 geese receiving the combination of diazepam/ketamine.

\section{Discussion}

There are few literature reports on the use of different combinations of anaesthetics for surgical procedures in geese. This study assessed the duration of individual anaesthesia periods in geese receiving a combination of diazepam/ketamine or xylazine/ ketamine. Achieving anaesthesia in birds using ketamine requires the use of a higher dose in relation to mammals, due to their weaker muscle relaxation, muscle tremors, contractions, arching of the body, and rough and extended awakening that can last from 40 to 100 minutes (SAMOUR et al., 1984; CHRISTENSEN et al., 1987; VALVERDE et al., 1993; MAMA et al., 1996; RITCHIE et al., 1997; GLEED and LUDDERS, 2001; VARNER et al., 2004). Some reports state that the level of surgical anaesthesia was not achieved despite the administration of higher doses of ketamine. For that reason, the use of ketamine exclusively as the sole anaesthetic for birds is not recommended (GUNKEL and LAFORTUNE, 2005).

The combination of ketamine with benzodiazepine or agonists of the $\alpha_{2}$-adrenoreceptors are administered to increase the depth of anaesthesia, to improve muscle relaxation and quality of awakening (ROSSKOPF et al., 1989; CARPENTER et al., 2001; VARNER et al., 2004). Therefore, in this study, ketamine was administered in combination with either xylazine or diazepam to increase the effects of ketamine and to allow for a reduction in its dose.

The negative aspects that appear with a combination of ketamine and $\alpha_{2}$ adrenoreceptor agonists include hypotension, bradycardia and partial AV-block, depending on the dosage. Hypothermia with reduced thermogenesis may occur, as well as an increased postoperative need for fluids, sedation and depression of the respiratory centre in waterfowl (MACHIN, 2002).

In all three groups, a drop in body temperature was recorded during anaesthesia. The body temperature values within the group of geese receiving the xylazine/ketamine combination declined gradually from the start of measurement to the time of raising the head, and achieved the lowest values at the final measurement time. In geese receiving the xylazine/ketamine combination, very significant reductions in body temperature at the time of raising the head were recorded in comparison to geese receiving the diazepam/ ketamine combination. Very significant reductions in body temperature were also observed during the measurement period in the group of geese receiving the $0.9 \% \mathrm{NaCl}$ 
solution. Therefore, the body temperature of geese anaesthetised using a combination of xylazine/ketamine should be monitored during the anaesthesia period, the animals should be kept warm and optimal temperatures maintained within the operating room.

During this study, a statistically significant drop in the respiratory rate was observed within the xylazine/ketamine group by $106 \%$ over the course of the measurement period, indicating depression of the respiratory centre. The occurrence of long, difficult expiration was also observed in 4 of 8 geese during the measurement period. No occurrence of difficult expiration was observed in the diazepam/ketamine group, and although there was a $59 \%$ drop in breathing frequency in that group, there were no statistically significant differences within that group. LUDDERS et al. (1989) examined the effects of ketamine and xylazine, administered independently and in combination, in Peking ducks, and they also reported the occurrence of respiratory depression in the groups of ducks receiving xylazine alone or in combination with ketamine.

The CO2 partial pressures in venous blood within the xylazine/ketamine group were significantly increased from the start of measurement to the time of raising the head. A statistically significant increase in $\mathrm{pCO} 2$ values was also observed in this group in comparison to the other groups at the time of raising the head. MUIR and DEMORAIS (1996) reported that hypercapnia is the consequence of hypoventilation, which is common during anaesthesia, and that hypoventilation may be caused by respiratory depression. An increase in pCO2 over $8 \mathrm{kPa}$ is a sign of severe respiratory depression. Respiratory acidosis results from hypoventilation. Therefore, the results presented here indicate the possibility that due to the respiratory depression caused by the anaesthetic, hypoventilation with respiratory acidosis ensued. Respiratory depression, particularly in geese, impacts the ventilation of the lungs and results in changes in the partial pressures of $\mathrm{CO} 2$ in blood, since geese have only seven and not nine sacci pneumatici (ONUK et al., 2009). The sacci pneumatici force air through the lungs, thereby enabling oxygenrich air to pass through the paleopulmonal bronchi during both inhalation and exhalation, which is a unique trait among vertebrates (ŠPERANDA, 2009). It may be assumed that due to the specific anatomy of the respiratory system in geese, particularly the reduced number of sacci pneumatici that are directly responsible for the quality of gas exchange in the lungs, these animals are more sensitive to substances that can cause respiratory depression. SAMOUR et al. (1984) stated that xylazine administered independently caused respiratory depression in certain bird species, and it may be assumed that a reduced concentration of xylazine in combination would avoid respiratory depression, although it is possible that the effects of ketamine would in that case become predominant.

In the time period from setting the head on the ground to the time of standing up again (the general anaesthesia period), excitation was observed in the form of uncontrolled, twitching movements in the legs in $75 \%$ geese in the group receiving the xylazine/ 
ketamine combination and in $37.5 \%$ geese receiving the diazepam $/$ ketamine combination. The possible cause of the appearance of increased muscle tone and contractions is the predominant effect of ketamine due to the high ratio of ketamine $(40 \mathrm{mg} / \mathrm{kg})$ vs. xylazine $(3 \mathrm{mg} / \mathrm{kg})$ in the combination. Similar side effects were observed by JAVDANI GANDOMANI et al. (2009) for budgerigars, in a study aimed to examine the degree and duration of intramuscular administration of anaesthesia with varying doses of ketamine $(20,40,60$ and $80 \mathrm{mg} / \mathrm{kg})$ in combination with xylazine $(10 \mathrm{mg} / \mathrm{kg})$. In this study, the longest anaesthesia period was achieved in the group of parrots receiving the combination of $80 \mathrm{mg} / \mathrm{kg}$ ketamine with $10 \mathrm{mg} / \mathrm{kg}$ xylazine, although side effects included increased muscle tone and convulsions. It may be assumed that these undesired effects of ketamine might have been avoided in the present study with a change in the ratio of xylazine and ketamine in the combination. If a lower dose of ketamine was used in the combination, it is likely that these side effects would have been milder or would not have appeared at all, and an additional consequence would be a shorter anaesthesia period and reduced analgesic effect of the ketamine needed to perform painful surgical procedures.

In the group of geese receiving the combination of diazepam/ketamine, the time period from the administration of the compound to lowering the head on the ground (start of anaesthesia) was statistically significantly shorter (average 3.33 minutes) than in geese receiving the xylazine/ketamine combination (average 8.05 minutes). This study partially corroborates other findings (TOMLINSON, 1994) that it can take up to 5 minutes for the effects of ketamine to begin. GREEN et al. (1981) examined the effectiveness of the combination of diazepam/ketamine in different bird species, and found that, in all species, diazepam administered in this combination in a dose from 2.0 $2.5 \mathrm{mg} / \mathrm{kg}$ drastically improved the effects of ketamine, and in some individuals, surgical anaesthesia was achieved faster. In the present study, a similar finding was seen based on the times needed to achieve anaesthesia. The study showed that anaesthesia was achieved significantly faster in the group of geese receiving the combination of diazepam/ketamine than in the group receiving xylazine/ketamine. A possible reason for these statistically significant differences in the time to achieve anaesthesia is the dose of xylazine $(3 \mathrm{mg} / \mathrm{kg})$ administered in the xylazine/ketamine combination, and the time to achieve anaesthesia may have been lower with a higher dose of xylazine in that combination. However, this increases the chances of the occurrence of more pronounced bradycardia.

In the group of geese receiving the diazepam/ketamine combination, the time period from setting the head on the ground to the first reaction of the distal phalanx to pressure from the Pean haemostat (surgical anaesthesia) was significantly longer (20.5 minutes) than in the group of geese receiving the xylazine/ketamine combination (12.4 minutes). SWINDLE et al. (2002) reported that diazepam in combination with ketamine causes anaesthesia by acting on part of the limbic system, thalamus and hypothalamus, resulting 
in a calming effect. It is possible that the xylazine/ketamine combination could achieve an extended duration of surgical anaesthesia, although this would require a change in the ratio of drugs in the combination, which could give rise to the occurrence of convulsions or pronounced bradycardia.

In geese receiving the combination of diazepam/ketamine, the time period from setting the head on the ground to the time of standing up again was significantly longer (202.6 minutes) than in the group receiving the xylazine/ketamine combination (118.5 minutes).

\section{Conclusion}

The results of the present study showed that the diazepam/ketamine combination was more acceptable for a number of indicators than the xylazine/ketamine combination for the anaesthesia of geese. However, it should be noted that the administration of other doses of both xylazine and ketamine in the xylazine/ketamine combination might have given different results, and therefore, it cannot be conclusively determined that the xylazine/ ketamine combination is not acceptable; rahter it may be concluded that the xylazine/ ketamine combination is not acceptable at the doses and in the ratio used in this study.

There were some limitations to this study that need to be emphasised. Arterial blood pressure measurements could have added important additional data about the effects of the studied anaesthetics. However, our methodology implied field conditions with the focus on short-term intramuscular anaesthesia combinations. Future studies comparing different long-term anaesthesia combinations are warranted.

\section{References}

CARPENTER, J. W., T. Y. MASHIMA, D. J. RUPIPER (2001): Exotic Animal Formulary, $2^{\text {nd }}$ ed., Saunders. Philadelphia, pp. 217-327.

CHRISTENSEN, R. T., R. T. FOSSE, O. J. HALVORSEN, I. MORLID (1987): Comparison of various anesthetic regimens in the domestic fowl. Am. J. Vet. Res. 48, 1649-1657.

CURRO, T. G. (1998): Anesthesia of pet birds. Sem. Avian Exot. Pet Med. 7, 10-21.

DOI: $10.1016 / \mathrm{S} 1055-937 \mathrm{X}(98) 80053-4$

GLEED, R. D., J. W. LUDDERS (2001): Recent Advances in Veterinary Anesthesia and Analgesia: Companion Animals. IVIS. Ithaca. New York Available form: http://www.ivis.org/advances/ Anesthesia_Gleed/paul/chapter.asp?LA $=1$.

GREEN, C. J., J. KNIGHT, S. PRECIOUS, S. SIMPKIN (1981): Ketamine alone and combined with diazepam or xylazine in laboratory animals: a 10 year experience. Lab. Anim.15, 163170.

DOI: $10.1258 / 002367781780959107$ 
A. Musulin et al.: Diazepam/ketamine and xylazine/ketamine effects in geese

GUNKEL, C., M. LAFORTUNE (2005): Current techniques in avian anesthesia. Semin. Avian Exot. Pet Med. 14, 263-276.

DOI: $10.1053 /$ j.saep.2005.09.006

HALL, L. W., K. W. CLARKE, C. M. TRIM (2001): Veterinary Anaesthesia, $10^{\text {th }}$ ed. Saunders. London, pp. 472-475

JAVDANI GANDOMANI, M., A. TAMADON, A. MEHDIZADEH, H. R. ATTARAN (2009): Comparison of different ketamine-xylazine combinations for prolonged anaesthesia in budgerigars (Melopsitacus undulatus). Vet. Scan. 4, 21-23.

LUDDERS, J. W., J. RODE, G. S. MITCHELL, E. V. NORDHEIM (1989): Effects of ketamine, xylazine, and a combination of ketamine and xylazine in Peking ducks. Am. J. Vet. Res. 50, 245-249.

MACHIN, K. L. (2002): Effects of surgery, anesthesia and pain on reproduction and behaviour of captive and free-ranging ducks. PhD Thesis, Department of Veterinary Biomedical Sciences, University of Saskatchewan. Saskatoon. Canada.

MACHIN, K. L. (2004): Waterfowl anesthesia. J. Exotic Pet. Med., 13, 206-212.

MACHIN, K. L., N. A. CAULKETT (1998): Cardiopulmonary effects of propofol and a medetomidine-midazolam-ketamine combination in mallard ducks. Am. J. Vet. Res. 59, 598-602.

MAMA, K. R., L. G. J. R. PHILLIPS, P. J. PASCOE (1996): Use of propofol for induction and maintenance of anesthesia in barn owl (Tyto alba) undergoing tracheal resection. J. Zoo Wildlife Med. 27, 397-401.

MUIR, W. W., H. S. A. DEMORAIS (1996): Acid-base balance: traditional and modified approaches. In: Lumb \& Jones Veterinary Anesthesia, $3^{\text {rd }}$ ed. (Thurmon, J. C., W. J. Tranquilli, G. J. Benson, Eds.) Williams \& Wilkins, Baltimore, Maryland, pp. 558-571.

ONUK, B., R. M. HAZIROGLU, KABAK, M. (2009): Gross anatomy of the respiratory system in goose (Anser anser domesticus): bronchi and sacci pneumatici. Ankara Univ. Vet. Fak. Derg. 56, 165-170.

DOI: 10.1501/Vetfak_0000002216

RITCHIE, B. W., G. J. HARRISON, L. R. HARRISON (1997): Avian Medicine, Principles and Application. Saunders. Philadelphia, pp. 1066-1074

ROSSKOPF, W. J., R. W. WOERPEL, S. REED (1989): Avian anesthesia administration. In: Proceedings of the American Animal Hospital Association. St. Louis. pp. 449-457.

SAMOUR, J. H., D. M. JONES, J. A. KNIGHT, J. C. HOWLET (1984): Comparative studies of the use of some injectable anaesthetic agents in birds. Vet. Rec. 115, 6-11.

DOI: $10.1136 /$ vr.115.1.6

SWINDLE, M. M., G. A. VOGLER, L. K. FULTON, R.P. MARINI, S. POPILSKIS (2002): Preanesthesia, anesthesia, analgesia and euthanasia. In: Laboratory Animal Medicine. $2^{\text {nd }}$ ed. (Fox, J. G., L. C. Anderson, F. M. Loew, F. W. Quimby, Eds.). Academic Press. California. pp. 956-1003.

DOI: $10.1016 / \mathrm{B} 978-012263951-7 / 50025-9$

Vet. arhiv 88 (6), 835-846, 2018 
A. Musulin et al.: Diazepam/ketamine and xylazine/ketamine effects in geese

ŠPERANDA, M. (2009): Morphology and physiology of domestic poultry. In: Poultry, Biological and Zootechnical Principles (Kralik, G., E. Has-Schön, D. Kralik, M. Šperanda, Eds.). Poljoprivredni fakultet u Osijeku, Sveučilište J. J. Strossmayera u Osijeku. pp. 145-208 (in Croatian).

TOMLINSON, A. (1994): City general hospital. Newcastle Red. Stoke on Trent. Staff (ST4 6QG). Practical procedures. Upd. Anesth. 4, 1-2.

VALVERDE, A., D. BIENZLE, D. A. SMITH, D. H. DYSON, A. E. VALLIANT (1993): Intraosseous cannulation and drug administration for induction of anesthesia in chickens. Vet. Surg. 22, 240-244.

DOI: $10.1111 / j .1532-950 X .1993 . t b 00392 . x$

VARNER, J., K. R. CLIFTON, S. B. S. POULOS, J. R. BRODERSON, R. D. WYATT (2004): Lack of efficacy of injectable ketamine with xylazine or diazepam for anesthesia in chickens. Lab. Anim. 33, 36-39.

DOI: 10.1038/laban0504-36

Received: 21 February 2018

Accepted: 17 October 2018

MUSULIN,A., M. ŠKULAC, M.VUČKOVIĆ,A. MARTINOVIĆ, P. KOSTEŠIĆ, N. BRKLJAČA BOTTEGARO, M. PEĆIN, D. VNUK: Učinci sedacije gusaka kombinacijom diazepama i ketamina te ksilazina i ketamina. Vet. arhiv 88, 835-846, 2018.

\section{SAŽETAK}

Cilj rada bio je usporediti učinke nakon intramuskularne primjene kombinacije diazepama i ketamina te ksilazina i ketamina u anesteziji gusaka. Mjereno je trajanje pojedinih perioda anestezije te njihov učinak na dišni i cirkulacijski sustav kako bismo uvidjeli koja je kombinacija sigurnija. Osam gusaka dobilo je kombinaciju ksilazina i ketamina, osam kombinaciju diazepama i ketamina, a šest je dobilo 0,9 \%-tni $\mathrm{NaCl}$. Tjelesna temperatura, frekvencija bila i disanja te biokemijske pretrage krvi s acido-baznim statusom venske krvi mjereni su odmah prije primjene lijekova, pet minuta nakon primjene te nakon što su guske počele podizati glavu. Guskama iz kontrolne skupine dodatno su učinjena mjerenja nakon 35 minuta. Razdoblje od primjene anestetika do spuštanja glave na tlo je bilo značajno kraće kod gusaka koje su primile kombinaciju diazepama i ketamina nego u gusaka s kombinacijom ksilazina i ketamina. Razdoblje od spuštanja glave na tlo do prve reakcije na pritisak na distalni članak prsta i razdoblje od primjene do ustajanja životinje bilo je značajno dulje kod gusaka s kombinacijom diazepama i ketamina. Tjelesna temperatura i frekvencija disanja bile su znatno niže u gusaka s kombinacijom ksilazina i ketamina. Parcijalni tlak $\mathrm{CO}_{2}$ bio je znatno viši za vrijeme anestezije kod gusaka s kombinacijom ksilazina i ketamina. Prema rezultatima ovog istraživanja može se zaključiti da anestezija gusaka s kombinacijom diazepama i ketamina pokazuje povoljnije učinke od kombinacije ksilazina i ketamina.

Ključne riječi: anestezija; guske; kardiorespiracijski učinci 